\title{
Resource Use Efficiency of Yam Production in Ekiti State, Nigeria.
}

\author{
Toluwase, S. O. W \\ Ekiti State University \\ Department of Agricultural Economics and Extension Services \\ Ado - Ekiti, Ekiti State, Nigeria. \\ A. B. Sekumade \\ Ekiti State University \\ Department of Agricultural Economics and Extension Services \\ Ado - Ekiti, Ekiti State, Nigeria.
}

\begin{abstract}
The study examined the resource use efficiency of yam production in Ekiti State, Nigeria. Multistage sampling techniques were used to select 120 respondents and were interviewed using a well structured questionnaire. The study described the socioeconomic characteristics of the farmers; indentify the system of land ownership and the constraints that yam farmers faced; and analyze the technical efficiency of the farmers. Descriptive statistics such as; frequency counts, mean and percentage was used while the inferential statistics used to estimate technical efficiency was stochastic frontier function. The findings revealed that the study area is dominated by male, married, experienced and small holder farmers with almost secondary school level of education. The mean and maximum technical efficiency was 0.87 and 0.99 respectively thus showing a high level of how yam farmers are technically efficient in the study area. The study recommended that government should provide adequate extension and supportive services with a view to improving farming techniques with technological innovation and farm inputs should be made available at highly subsidized rates through adequate and efficient distribution to the farmers.

Keywords:- Resource, Efficiency, Yam, Production, Ekiti.
\end{abstract}

\section{INTRODUCTION}

Nigeria's socio-economic history and development has been very closely tied to its agricultural sector (Egbuna, 2008). Agriculture holds the key to rural development, poverty alleviation and overall economic development (Oluwafemi et al., 2010). The sector accounted for about 3142\% of Gross Domestic Product (GDP) between the year 2005 and 2008. In addition, it provided paid and self employment for over 70\% of the nation's population (Nigerian Export Promotion Council (NEPC), 2009). The Food Crop Sub-sector (with maize, sorghum, millet, rice, yam, cocoyam and cassava as the main food crops grown in the country) contributed about $28 \%$ to GDP representing about $75-76 \%$ of the share of the agricultural sector's contribution to GDP (CBN, 2012).

Root and tuber crops comprise crop covering several genera. They are staple food crops, being the source of daily carbohydrate intake for the large populace of the world. The term root and tuber crop refers to any growing plant that store edible materials in the subterranean root, corm or tuber (Oke, 1990). Yam is a member of this important class of food. 
Yams (Dioscorea spp) are annual or perennial tuber-bearing and climbing plants with over 600 species out of which six are economically important in terms of food and medicine (IITA, 2007). Yam belongs to the genus "Dioscorea" and family "Dioscoreaceae". It is an important tuber crop of the tropics. Yam is a tropical crop with many species, which originated from South East Asia and was brought to West Africa in the 16th century. It is one of the principal tuber crops in the Nigeria economy, in terms of land under cultivation and in the volume and value of production (Bamire and Amujoyegbe, 2005). FAO (2002) reported that Nigeria accounted for about 71\% (26 000000 tons) of the total world production of yam harvested from 2,760 ha. Yam production in Nigeria has more than tripled over the past 45 years from 8.7 million tons in 1961 to 31.3 million tons 2006. This increase in output is attributed more to the large area planted to yam than to increased productivity (Izekor and Olumese, 2010). Though the area cultivated to yam production is still being increased, production growth rate declined tremendously from average of $27.5 \%$ between 1986 and 1990 to $3.5 \%$ in the period between 1991 and 1999 (FAO, 2002). However, between 2001 and 2006 production growth rate increased by $31.3 \%$. Record of yield showed similar trend during the same period. Average yield per hectare dropped from 14.9\% between 1986 and 1990 to 2.5\% in the period between 1991 and 1999. However, the period between 2001 and 2006 recorded 23.4\% increase in the average yield (Izekor and Olumese, 2010).

On the basis of quantity of root and tuber crops produced in Nigeria, yam ranks second to cassava. Yam is the perfect staple food appreciated in its state and cultural role. It is a major source of energy in diet of Nigeria people. Yam can be eaten when boiled, roasted, baked or fried. It can also be processed into crude flour by drying thin slices in the sun and then pound or ground into flour. Yam can further be processed into instant flakes producing a food similar to instant potato and can also be made into fried chip. Most of starch industries also make use of yam as one of their important raw materials. It provides job opportunities and income to both the producers and the marketers. Yam peels serve as feed for livestock and as a good component of farm yard manure. It is used as laboratory crop for scientific investigations.

According to Okenwe, Orewa and Emokaro (2008), yam contains a high value of protein (2.4\%) and substantial amount of vitamins and minerals than some other common tuber crops. It is also comparable to any starchy root crops in energy and the fleshy tuber is one of the main source of carbohydrates in the diet of most Nigerians. Yam also plays vital roles in traditional culture, rituals and religion; as well as local commerce of African people (Izekor and Olumese, 2010). Medicinally, yam tubers are used for various traditional medicines in China, Korea and Japan (USDA, 2009). It contributes more than 200 dietary calories per capita daily for more than 150 million people in West Africa and also an important source of income generation and trade (Reuben and Barau, 2012).

The study of efficiency in agriculture is based or found on certain economic theories. These theories serve as the framework for this study.

The production function stipulates the technical relationship between inputs and output in the production process (Olayide and Heady, 1982). The modern theory of efficiency dates back to the pioneering work of Farrel (1957), who drew extensively from the earlier works of Debreu (1951) and Koopmans (1951) to define a simple measure of firm efficiency, which could account for multiple inputs. Farrel identified two components of firm efficiency as technical and allocative efficiencies and the combination of these two components provides a measure of economic efficiency (Udoh, 2005). Technical efficiency, the main issue in this study can be 
measured either as input conserving oriented technical efficiency or output expanding oriented technical efficiency. Output expanding oriented technical efficiency is the ratio of observed to maximum feasible output, conditional on technical and observed input usage (Jondraw et al., 1982; Ali, 1996; Udoh, 2005).

Technical efficiency is based on expressing the maximum amount of output obtainable from given bundles of production resources with fixed technology. It is the attainment of production goods without wastage (Amaza and Olayemi, 1999). This is regarded as estimating average production function (Olayide and Heady, 1982).

Allocative efficiency on the other hand relates to the degree to which a farmer utilizes inputs in optimal proportions, given the observed input prices (Coelli et al., 2002; Ogundari et al, 2006). According to Adesina and Djato (1997), economic efficiency occurs when a firm chooses resources and enterprises in such a way as to attain economic optimum. The optimum implies that a given resource is considered to be most efficiently used when its marginal value productivity is just sufficient to offset its marginal cost. Thus, economic efficiency refers to the choice of the best combination for a particular level of output which is determined by both input and output prices. This would lead to increase in the farmers output as well as its income invariably leading to poverty reduction, providing food security, improved living condition and wellbeing.

Measurement of farm efficiency via frontier approach has been widely utilized and studied. The term frontier involves the concept of maximality in which the function sets a limit to the range of possible observations (Forsund et al., 1980). The observation of points below the production frontier for firms producing below the maximum possible output can occur, but there cannot be any point above the production frontier given the available technology. Deviations from the frontier are attributed to inefficiency. Frontier studies are however classified according to the method of estimation. Kalaizandonakes et al. (1992) grouped these methods into two broad categories - parametric and non-parametric methods. The parametric method can be deterministic, programming and stochastic depending on the specification of the frontier model. Many researchers including Schmidt (1976) have argued that efficiency measures from deterministic models are affected by statistical noise. This however led to the alternative methodology involving the use of the stochastic production frontier models. The major feature of the stochastic production frontier is that the disturbance term is a composite error consisting of two components; one symmetric, the other one-side component. The symmetric component, Vi. captures the random effects due to measurement error, statistical noise and other influences, and is assumed to be normally distributed. The one-sided component Ui. Captures randomness under the control of the firm. It gives the deviation from the frontier attributed to inefficiency. It is assumed to be either half-normally distributed or exponentially distributed.

By definition, stochastic frontier production function is

$\mathrm{Yi}=\mathrm{F}(\mathrm{Xi} ; \beta) \exp (\mathrm{Vi}-\mathrm{Ui}) \mathrm{i}=1,2, ., \mathrm{N}(1)$

Where Yi is the output of the ith firm; $\mathrm{Xi}$ is the corresponding (MX2) vector of inputs; $\mathrm{b}$ is a vector of unknown parameter to be estimated; $F($.$) denotes an appropriate form, \mathrm{Vi}$ is the symmetric error component that accounts for random effects and exogenous shock; while Ui < 0 is a one sided error component that measures technical inefficiency. 
Several empirical applications have followed the stochastic frontier specification. The first application of the frontier model to farm level data was by Battese and Coelli (1995) who estimated deterministic and stochastic Cobb-Douglas production frontier for the economics of scale in sheep production in Australia. The variance of the farm effects was found to be in a highly significant proportion of the value of sheep production in Australia. Their study did not, however, directly address the technical efficiency of farms. Similarly, Bagi (2004) employed the stochastic frontier Cobb-Douglas production function model to investigate differences in technical efficiencies of sole and mixed enterprise farm in West Tennessee. The study found that the variability of farm effects was highly significant. The mean technical efficiency of mixed enterprise farms was found to be smaller (0.76) than for sole crop farms (0.85). The study show that, mixed enterprise farms were inefficient as compare to the sole crop farms as demonstrated by their various efficiency ratios.

The use of the stochastic frontier analysis in the study of agriculture in Nigeria is a recent development. Such studies include that of Udoh (2003), Okike (2006) and Amaza (2000). Udoh (2003) used the Maximum Likelihood Estimation of the stochastic production function to examine the land management and resource use efficiency in South-Eastern Nigeria. The study found a mean output -oriented technical efficiency of $77 \%$ for the farmers, this indicates that farmers can still expand production by $23 \%$. The 0.98 indicates $98 \%$ for the most efficient farmers and 0.11 indicating 11\% for the least efficient farmers. Okike (2006) investigated crop livestock interaction and economic efficiency of farmers in the Savanna Zones of Nigeria. The study found average economic efficiency of farmers are higher in the low-population -low Market domain; Northern Guinea Sudan Savanna ecological zones; and crop -based Mixed Farmers farming system. Also Amaza (2000) work on small scale farm size and resource use efficiency in Kwara state, opined that, one of the means of proper utilization of farm inputs for greater efficiency is through farm size adjustment. The result was collaborated by the mean cost efficiency of 1.161 obtained from the data analysis which shows that an average farm in the sample area is about $16 \%$ above the frontier cost, indicating that they are relatively efficient in allocating their scarce resources.

\section{PROBLEM STATEMENT}

In Nigeria, yam cultivation still depends largely on traditional hoes and cutlass techniques of production. Many aspect of production like clearing, planting, weeding, stalking and harvesting which require considerable inputs of labour are still been done manually.

Although, Nigeria is a global leader in yam production, most of the yams produced are also consumed within Nigeria with little or no exportation at all. In Ekiti State, yam production is of high economic benefit to the people due to amount of resources committed to its production and the proportion of their income which it represents. Prevalent food scarcity is becoming common problem in Nigeria because as a developing nation which is tending towards industrial economy from agricultural economy. Nigeria is said to be experiencing a progressive and rapid population growth with the attendant increase in the demand for food crops.

Resources are considered to be at its highest and best use when it is put into use with highest comparative advantage to other uses. Efficiency of resource use can therefore be assessed from the productivity of the output. This is an important issue of the present time, because resource use efficiency issues are the core elements of sustainable crop production of small-scale farming activities. Inefficient use of inputs can jeopardize food availability and its security. It is 
therefore imperative to know whether resources are used efficiently in yam production in the study area.

\section{OBJECTIVES OF THE STUDY}

The main objective of this study is to determine how efficiently resources are used in the production of yam in the study area. The specific objectives are:

- to describe the socio economic characteristics of yam farmers in the study area

- to determine the system of land ownership by the farmers

- to identify the major constraints to yam production in the study area and proffer a possible solution; and

- to determine the technical efficiency of resource used in yam production in the study area.

\section{The study Area}

\section{METHODOLOGY}

The study was carried out in Ekiti State Nigeria. The state was created on 1st October 1996 out of the former Ondo State. The State is bounded on the south and on the East by Ondo State, on the west by Osun State and on the northern side by Kwara and Kogi State. The State is presently made up of 16 Local Government Areas. The State is situated entirely within the tropics.

Ekiti state is located between longitude 400 51' and 500 451' East of the Greenwich meridian and latitude $700151^{\prime}$ and 800 51' North of the equator. It has an area of 58,887.890sqkm and temperature of between $210 \mathrm{c}$ and $280 \mathrm{c}$ with high relative humidity. The vegetation of Ekiti state is guinea forest including all forms of fauna and flora with an annual rainfall of $1,400 \mathrm{~mm}$.

The climate of the State is tropical with two distinct seasons, the rainy season which last from April to October and dry season from November to March. The main occupation of the people are farming and trading. The major agricultural crops include yam, cassava, maize, cocoyam, tomato among others.

\section{Method of Data collection}

The data used for this study were essentially from primary sources. The data was collected through the use of well structured questionnaire.

\section{Sampling Techniques}

A multistage simple random sampling technique was used to select 120 respondents from the state. Three (3) local governments' areas were selected randomly from the state, five (5) villages were also selected from each of the selected local government areas, and this was followed by another selection of eight (8) respondents in each of the selected villages. Therefore a total of 120 respondents were considered during the study.

\section{Analytical Technique}

The data collected were subjected to descriptive analysis. Tools such as mean, median, frequency distribution, percentage were used to analyze and categorize the socio - economic characteristics of the respondent and problems militating against them in the study area.

Stochastic frontier 4.1 version model developed by Battese and Coelli (1995) were used to analyze the technical efficiency and inefficiency of farmers in the study area. 


\section{Model Specification}

The stochastic frontier model makes use of Cobb-Douglas model estimate (double log). It comprises both efficiency parameter and inefficiency parameter. The model is explicitly specified as;

$\operatorname{Ln} \mathrm{Yi}=\beta 0+\beta 1 \ln \mathrm{X} 1+\beta 2 \ln \mathrm{X} 2+\beta 3 \ln \mathrm{X} 3+\beta 4 \ln \mathrm{X} 4+\beta 5 \ln \mathrm{X} 5+\beta 6 \ln \mathrm{X} 6+\beta 7 \ln \mathrm{X} 7-(\mathrm{Ui})$

Where

$\mathrm{Y}=$ Revenue from yam produce $(\mathrm{H})$

$\beta 0=$ Constant estimate for efficiency model

X1- X7 =Efficiency parameters

$\mathrm{X} 1$ = Land area cultivated (ha)

$\mathrm{X} 2=$ Labour cost $(\mathrm{N})$

$\mathrm{X} 3$ = Cost of land preparation $(\mathrm{N})$

$\mathrm{X} 4=$ Cost of yam sett $(\mathrm{A})$

$\mathrm{X} 5=$ Cost of weeding ( $\mathrm{A})$

$\mathrm{X} 6=$ Harvesting cost $(\mathrm{N})$

$\mathrm{X} 7=$ Transportation cost $(\mathrm{N})$

Where

$\mu \mathrm{i}$ are the inefficiency parameters

$\mu \mathrm{i}=\delta \mathrm{o}+\delta_{1} Z_{1}+\delta_{2} Z_{2}+\delta_{3} \delta_{3}+\delta_{4} Z_{4}+\delta_{5} Z_{5}+\delta_{6} Z_{6}+\delta_{7} Z_{7}$

Where

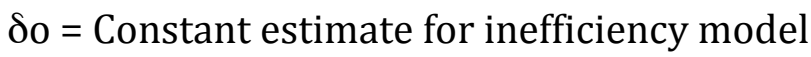

$1=$ Gender (male $=1$, female $=0$ )

$2=$ Age of farmers (years)

3 = Marital status (single 0, married 1, widowed 2)

$4=$ Household size

5 = Farming experience

$6=$ Level of education

7 = Government support $($ Yes $=1$, No $=0)$.

\section{Socio-economic Characteristics of the Respondents \\ RESULT AND DISCUSSION}

Table 1 revealed the age categorization of respondents. $5 \%$ of the respondents falls below the age of 31 years while $16.7 \%$ are above 60 years. The mean age was 49.1 revealing that majority of the farmers are quiet mature. The implication of this is that most of the farmers were adult with much energy and as such could be so efficient in their farming activities, hence their output or productivity will be quite high, compared to that of the old- age because the adult are still vibrant and has energy to cope with stress of farming.

The table also shows the distribution of farmers according to their gender. The table revealed that $83.3 \%$ of yam farmers were male while $16.7 \%$ were female. This could be attributed to the energy demanding activities involved in yam production which require men who are naturally endowed with abundant strength necessary for such jobs.

The marital status of the respondents shows that $84.2 \%$ of yam farmers were married, only $12.5 \%$ were single and $3.3 \%$ were widow. The very high percentage of the married yam producers can be attributed to the fact that respondents require helping hands to carry out the processes of yam production. 
The table also revealed that $44.2 \%$ of the respondents had household size below $5,50 \%$ of the respondents had household size between $5-10$, while $5 \%$ of the respondents had households size between 11-15 and $0.8 \%$ of the respondents had household size above 15 . The implication is that as the household size become larger, the efficiency could increase because what needed to be done on the farm was done on time since large household size increases the opportunity for family labour usage

From the table, $38.3 \%$ of the farmers had no formal education, $12.5 \%$ had informal education, $22.5 \%$ had primary education, while $15 \%$ had secondary education, and the remaining $11.7 \%$ had tertiary education. The educational level is expected to have a positive influence on the adoption of improved technologies such as farm mechanization, which would have high potentials to increase farm productivity.

The farming experience of respondents shows the number of years the farmers had been into yam production. $45 \%$ of the respondents had farming experience below 11 years, $25 \%$ had farming experience ranges from 11-20 years, 14.1 had farming experience ranges from 21-30 years, while $11.7 \%$ had farming experience ranges from $31-40$ years and $4.2 \%$ had farming experience above 40 years. There could be increase in yam production as the average farming experience was 16.5 years.

The distribution of respondents on the basis of farm size shows that the respondents that cultivated between 1 - 4 ha were $45 \%, 20 \%$ of the respondents had farm size ranges from 4.18 ha and $11.7 \%$ had farm size above 12 ha. The mean farm size cultivated was 3.6 ha. This implies that majority of the respondents are small farm holders. 
Table 1: Socio-economic Characteristics of the Respondents

\begin{tabular}{|c|c|c|}
\hline Variables & Frequency & Percentage \\
\hline \multicolumn{3}{|l|}{ Age (years) } \\
\hline$<31$ & 6 & 5 \\
\hline $31-40$ & 19 & 15.8 \\
\hline $41-50$ & 42 & 35 \\
\hline $51-60$ & 33 & 27.5 \\
\hline$>60$ & 20 & 16.7 \\
\hline \multicolumn{3}{|l|}{ Gender } \\
\hline Male & 100 & 83.3 \\
\hline Female & 20 & 16.7 \\
\hline \multicolumn{3}{|l|}{ Marital Status } \\
\hline Married & 101 & 84.2 \\
\hline Single & 15 & 12.5 \\
\hline Widow & 4 & 3.3 \\
\hline \multicolumn{3}{|l|}{ Household Size } \\
\hline$<5$ & 53 & 44.2 \\
\hline $5-10$ & 60 & 50 \\
\hline $11-15$ & 6 & 5 \\
\hline$>15$ & 1 & 0.8 \\
\hline \multicolumn{3}{|l|}{ Educational Level } \\
\hline No Formal Education & 18 & 15 \\
\hline Informal Education & 15 & 12.5 \\
\hline Primary Education & 27 & 22.5 \\
\hline Secondary Education & 46 & 38.3 \\
\hline Tertiary Education & 14 & 11.7 \\
\hline \multicolumn{3}{|c|}{ Farming Experience (years) } \\
\hline$<11$ & 54 & 45 \\
\hline $11-20$ & 30 & 25 \\
\hline $21-30$ & 17 & 14.1 \\
\hline $31-40$ & 14 & 11.7 \\
\hline$>40$ & 5 & 4.2 \\
\hline \multicolumn{3}{|l|}{ Farm Size (Ha) } \\
\hline $1-4$ & 54 & 45 \\
\hline $4.1-8$ & 24 & 20 \\
\hline $8.1-12$ & 28 & 23.3 \\
\hline$>12$ & 14 & 11.7 \\
\hline
\end{tabular}

Source: Field Survey, 2014.

\section{Farming Related Activities of the Respondents}

Table 2 shows the farming related activities of the respondents. From the table, it was revealed that $52.5 \%$ of the respondents were fulltime farmers while $47.5 \%$ of the respondents were part time farmers. In Nigeria, most farmers engage in other income generating activities apart from farming. This is a way of generating additional income in order to ensure food security for the family. 
However, it cannot be ruled out that several other farmers still depends solely on agriculture. Therefore it is relevant to categorize the respondent into either full time or part time occupation.

The table also shows the labour utilized by the yam Farmers. Finding reveals that $65.0 \%$ of the farmers used hired labour to work on the farm, while $24.2 \%$ used family labour and $10.8 \%$ used both family labour as well as hired labour.

The system of land ownership of respondents revealed that $57.5 \%$ acquired their farm land through inheritance, $20 \%$ had theirs through purchase, $15.8 \%$ through rents, while 6.5 was through gift. The results revealed that majority of the farmers owned their land through inheritance in the study area. Land is a fixed asset and constitutes a great limitation to Nigeria farmers.

The table in addition shows that $61.7 \%$ of the respondents planted different varieties of yam, while 38.3 planted only one variety of yams. Planting different varieties could be a strategy to avert production risk, crop failure and the infestation of pest and diseases confronted by farmers in the study area.

Also from the table, $34.2 \%$ of the respondents intercropped yam with maize on their farms. $20.8 \%$ (with cassava), $13.3 \%$ (with rice), $11.7 \%$ (with cocoyam), $8.3 \%$ (with plantain), in the same vein, $5.0 \%$ practice mono-cropping, while $4.2 \%$ (with vegetables) and $2.5 \%$ ( with tomatoes). It was observed that most of the farmers practice intercropping as a result of scarcity of land. Those farmers that intercropped their farm are likely to have less risk; since multiple cropping is a risk minimizing strategy. They derive other sources of income in case yam production fails.

Finally, the table shows that $45.0 \%$ of the respondents had their source of yam setts from their previous production, $30.0 \%$ from market, while $18.3 \%$ from agric inputs agencies like ADP and $6.7 \%$ from friends and relatives. This implies that most farmers set aside part of their produce for planting, while the role of input supplier in the study area was minimal. 
Table 2: Farming Related Activities of the Respondents

\begin{tabular}{|c|c|c|}
\hline Variables & Frequency & Percentage \\
\hline \multicolumn{3}{|l|}{ Mode of Farming } \\
\hline Full time & 63 & 52.5 \\
\hline Part time & 57 & 47.5 \\
\hline \multicolumn{3}{|c|}{ Type of Labour Utilized } \\
\hline Hired Labour & 78 & 65.0 \\
\hline Family Labour & 29 & 24.2 \\
\hline Both & 13 & 10.8 \\
\hline \multicolumn{3}{|c|}{ Ownership of Farm Land } \\
\hline Gift & 8 & 6.7 \\
\hline Inheritance & 69 & 57.5 \\
\hline Purchase & 24 & 20.0 \\
\hline Rent & 19 & 15.8 \\
\hline \multicolumn{3}{|c|}{ Cultivate Varieties of Yam } \\
\hline Yes & 74 & 61.7 \\
\hline No & 46 & 38.3 \\
\hline \multicolumn{3}{|c|}{$\begin{array}{l}\text { Intercropping of Yam with Other } \\
\text { Crops }\end{array}$} \\
\hline Tomatoes & 3 & 2.5 \\
\hline Vegetables & 5 & 4.2 \\
\hline Plantain & 10 & 8.3 \\
\hline Cocoyam & 14 & 11.7 \\
\hline Rice & 16 & 13.3 \\
\hline Cassava & 25 & 20.8 \\
\hline Maize & 41 & 34.2 \\
\hline None (Sole Crop) & 6 & 5.0 \\
\hline \multicolumn{3}{|l|}{ Sources of Yam Sett } \\
\hline Previous Production & 54 & 45 \\
\hline Market & 36 & 30.0 \\
\hline Agric Input Agencies & 22 & 18.3 \\
\hline Friends \& Relatives & 8 & 6.7 \\
\hline
\end{tabular}

Source: Field Survey, 2014.

\section{Constraints Encountered in Yam production}

Table 3 reveals the constraints faced by farmers during yam production process. These constraints were lack of government assistance, pest and diseases, lack of credit facilities, inadequate labour supply and poor extension services to mention but few. 
Table 3: Distribution of the constraints encountered in Yam Production

\begin{tabular}{lll|}
\hline Constraints & Frequency & Percentage \\
\hline Lack of govt. assistance & 19 & 15.8 \\
Pest and diseases & 24 & 20 \\
Lack of credits/ loaning facilities & 38 & 31.7 \\
Inadequate labour supply & 16 & 13.3 \\
Poor extension services & 23 & 19.2 \\
Total & 120 & 100 \\
\hline
\end{tabular}

Sources: Field Survey, 2014.

\section{Respondents' perception of solution to problem faced}

Table 4, reveals the perception of solution to the problems by the respondents. The problems could be ameliorating through the use of resistance varieties, extension agent stimulation, provision of rural amenities and provision of credit facilities. This could reduce rural- urban drift, and then the interest of youth in agriculture would be revamped, hence improve the availability of farm labour.

Table 4: Respondents perception of solutions to problems faced

\begin{tabular}{lcl}
\hline Ways & Frequency & Percentage \\
\hline Using resistance varieties & 27 & 22.5 \\
Rural infrastructure & 19 & 15.8 \\
Extension Agent Stimulation & 20 & 16.7 \\
Provision of credit facilities & 54 & 45.0 \\
Total & 120 & 100 \\
\hline
\end{tabular}

Source: Field Survey, 2014.

\section{The Final Maximum Likelihood Estimate}

Table 5, below showed the stochastic frontiers result on respondents using frontier 4.1 according to Battese and Coelli (1995). Variables that were significant among the efficiency parameters were cost of yam sett (1\%), cost of land preparation (1\%) and cost of land area (5\%). These significant variables exhibited positive coefficient. This implies a direct relationship between these variables and the returns on yam output. However, the more the area of land cultivated, consequently leading to higher cost of land preparation and increased planting cultivars, the more will be the output or returns on yam produced. These were however, the most significant variable that determines the technical efficiency among yam producers in the study area.

Although cost of labour was not significant but exhibited a negative sign of coefficient. This implies an inverse relationship between costs of weeding and output of yam produced. Harvesting cost and transportation cost had positive signs but not significant. The increasing 
cost on harvesting and transportation will also provide more returns for farmers. The produce could be moved to more areas attracting good prices for yam sales (place utility).

Educational levels and gender variables were significant at $1 \%$ and $5 \%$ respectively. These significant variables exhibited positive signs too. The implication of this is that male farmers were more efficient and derive higher returns than their female counterparts. Also, the more the level of education of farmers the higher his returns. This could be due to increased technical knowhow, accessibility to new innovation and marketing information. Age variable had an inverse relationship with output returns on yam production although not significant. This implies that production tends to decline as farmers grow older.

Household size exhibited positive sign and not significant. Production could be increased if farmers employ their families to participate in farming activities, thus decreasing the cost of hired labour and consequently increases return. Likewise, farming experience exhibited positive sign of coefficient, although not significant. This implies that the more the farming experiences of the farmers the more their returns.

In addition, the estimated sigma $(\delta 2)$ of 0.106 which was significant at $10 \%$ level indicated a good fit of the model, while the estimated gamma ( $\mathrm{g}$ ) of 0.15 obtained about $15 \%$ of the variation in yam farmers productivity was due to differences in farmers practices rather than random variables.

Table 5: Distribution of the final Maximum Likelihood estimate

\begin{tabular}{|c|c|c|c|c|c|}
\hline$\underline{\text { Variables }}$ & \multicolumn{2}{|c|}{ Parameters } & Coefficient & T-value & Stand. Error \\
\hline \multicolumn{6}{|l|}{ Production factor } \\
\hline Efficiency constant & \multicolumn{2}{|l|}{ ßo } & 0.717375 & 0.709970 & 0.101043 \\
\hline Land (ha) & \multicolumn{2}{|l|}{$\beta 1$} & $0.180430 * *$ & 0.245173 & 0.735927 \\
\hline Labour (N) & \multicolumn{2}{|l|}{$\beta 2$} & -0.130254 & -0.951152 & 0.136943 \\
\hline Land preparation ( & \multicolumn{2}{|c|}{$\beta 3$} & $0.882488 * * *$ & 0.103589 & 0.851910 \\
\hline Cost of yam setts (N) & \multicolumn{2}{|l|}{$\beta 4$} & $0.165678 * * *$ & 0.135551 & 0.122225 \\
\hline Cost of weeding (N) & \multicolumn{2}{|l|}{$\beta 5$} & -0.894622 & -0.622359 & 0.143747 \\
\hline Harvesting cost ( $)$ & \multicolumn{2}{|l|}{$\beta 6$} & 0.112526 & 0.886545 & 0.1269258 \\
\hline Transportation cost & \multicolumn{2}{|l|}{$\beta 7$} & 0.403395 & 0.4599013 & 0.877133 \\
\hline \multicolumn{6}{|l|}{ Inefficiency effects } \\
\hline \multicolumn{2}{|c|}{ Inefficiency model constant } & So & 0.249145 & 0.279034 & 0.8928827 \\
\hline \multicolumn{2}{|l|}{ Age (years) } & $\delta_{1}$ & -0.165362 & -0.670462 & 0.2466395 \\
\hline \multicolumn{2}{|l|}{ Household size (No) } & $\delta_{2}$ & 0.344599 & 0.3145701 & 0.109549 \\
\hline \multicolumn{2}{|c|}{ Farming experience (years) } & $\delta_{3}$ & 0.552083 & 0.960061 & 0.575050 \\
\hline \multicolumn{2}{|l|}{ Educational levels } & $\delta_{4}$ & $0.48231919 * * *$ & 0.126393 & 0.381601 \\
\hline \multicolumn{2}{|l|}{ Gender } & $\delta_{5}$ & $0.333865^{* *}$ & 0.236589 & 0.141116 \\
\hline
\end{tabular}




$\begin{array}{lllll}\text { Marital status } & \delta_{6} & -0.537590 & -0.400098 & 0.134365 \\ \text { Government support } & \delta_{7} & -0.232045 & -0.6427308 & 0.361029\end{array}$

Diagnostic statistics

\begin{tabular}{lllll} 
Sigma- square & $\delta^{2}$ & $0.105549^{*}$ & 0.684697 & 0.1541545 \\
Gamma & $\gamma$ & $0.147443^{* *}$ & 0.243391 & 0.6057878 \\
\hline
\end{tabular}

Asterisk indicate significance 1\% (***, $x \geq 2.617), 5 \%$ (**, $2.617>x \geq 1.960), 10 \%$ (1.645-1.959)

Source: Field Survey, 2014.

\section{Technical Efficiency}

Table 6, presents the distribution of technical efficiency of yam farmers. The average technical efficiency score was 0.87 . This implies that average yam farmers in the study area could increase their productivity by $13 \%$ with improving technical and allocative efficiency in their yam production. Only $13 \%$ of yam farmers were technically inefficient, while $87 \%$ allocated their resources efficiently.

Table 6: Distribution of Technical Efficiency

\begin{tabular}{lll} 
Technical Efficiency & Frequency & Percentage \\
\hline $70-80$ & 33 & 27.5 \\
$81-90$ & 49 & 40.8 \\
$>90$ & 38 & 31.7 \\
Total & 120 & 100 \\
Mean Efficiency & 0.87 & \\
Minimum Efficiency & 0.74 & \\
Maximum Efficiency & 0.99 &
\end{tabular}

Source: Field Survey, 2014.

CONCLUSION

The study measured the resource use efficiency in yam production using the stochastic parametric estimation method.

The study area is dominated by aged male, married, experienced and small holder farmers who mostly attained secondary level of education. Most of the farm cultivated was inherited.

\section{RECOMMENDATION}

In line with the findings of this study, the following recommendations are made:

- Farmers should be provided with improved planting materials to boost productivity in the area

- Provision of adequate extension and supportive services of government with a view to improving farming techniques with technological innovations

- The use of farm- level simple machine that the farmers can easily adopt should be encouraged.

- Farm inputs should be made available at highly subsidized rates and make them available timely, through adequate and efficient distribution. 


\section{References}

Adesina, A.A. and Djato, K.K (1997). "Relative efficiency of women as farm managers: profit function approach", cote d'voire, journal of Agricultural Economics. 16:47-53.

Ali M. 1996. Quantifying the socio-economic determinants of sustainable crop production. Agric. Eco. 14:45-46. Amaza, P.S. and Olayemi; J.k. (1999). An investigation of production efficiency in food crop Enterprises Gombe State, Nigeria, Journal of Rural Economics and Development 13:111-112.

Amaza, P.S. (2000), Efficiency of food crops production in Gombe State in Gombe, J. (2000). University of Ibadan, Ibadan.

Bamire A.S., Amujoyebe B.J. (2005) . Economic Analysis of Land Improvement Techniques in Small holder. YamBased production systems in the Agro-Ecological zones of south western, Nigeria. J. Human Ecol. 18(1): 1-12.

Battese, G.E. and T.J. Coelli, A model for technical inefficiency effects in stochastic Frontier Production for panel data, Empirical Economics, 20(1995); 325-345.

Bravo; U. 1994. Efficiency in Agricultural Production. The case of Peasant Farmers in Eastern Paraguay. Agric. Econ. J., 10:27-37.

Central Bank of Nigeria (CBN, 2012), Annual Report and statement of Account Report and statement of Account for the Year ended 31st December, 2007. Abuja, Nigeria, CBN publication.

Debreu, G., 1951. The coefficient of resource utilization, Econonometrica, 19-273-292.

Ekunwe P.A., Orewa S.I., Emokano C.O. (2008). Resource use efficiency in yam production in Delta and Kogi States in Nigeria. Asian J. Agric. Res. 2:61-69.

Egbuna, E.N. (2008), A review of the activities of the national strategic grains reserve: issue arising, C.B.N bullion, April - June, 2003, (2008), 42-45.

Eyoh; E.O. and S.I. Igben, 2002. Agricultural Economics. An Introduction to Basic concepts and principles. P.238. Best Print Bussiness Press, Uyo, Nigeria.

Farrel, M.J. (1957). The measurement of production efficiency. Journal of Royal Statistical Society, Series A, 120: 252-281

Food and Agricultural Organization (FAO), (2002). Food and Agricultural Organization Year Book. P. 56.

Food and Agricultural Organization (FAO, 2012). The state of food insecurity in protection crisises. FAO of the United Nations. Rome 2010. www.fao.org/docrep/013/i16830.pdf.

F.J. Baji, Stochastic Frontier Production function and farm-level efficiency of full time and part time farms in Tennessee, N. cent.J. Agric. Econ, 6(2004), 48-55

Forsund FR, Lovell K, Schmidt P (1980). A Survey of Frontier Production Functions and their relationship to efficiency measurement. J. Econometrics, 13:5 - 25.

IITA (2007): Root and Tuber system: Yam. International Institute for Tropical Agriculture, Ibadan.

Izekor O.B. Olumese M.I. (2010). Determinants of yam production and profitability in Edo State, Nigeria. Afr. J. General. Agric. 6(4): 30-35.

Jondraw, J., C,A. Lovel , I.S. Materou and P. Schumidt, 1982. On the estimation of technical in efficiency in the stochastic frontier production function model, J. Eco., 19:233-238.

Kalaitzandonakes, N. G. W. Shua Xiang and M. Jianahum (1992). Relationship between Technical Efficiency and Farm size revisited. Can. J. Agric. Econ. 40:427-442.

Koopmans, T.C., 1951. Analysis of production as an efficient combination of activities. In Koopmans, T.C.(ed). Activities analysis of production and allocation, cowles commission for research in Economics, monograph No 13. Widely, New York.

Nigeria Export Promotion Council (NEPC/2009). Percentage contribution of agriculture to Nigeria GDP Retrieved from http.www.economic confidential.com/may09interviewnepc.htm.

Okike, I. (2006), Crop, livestock interaction and economic efficiency of farmers in the savanna zone of Nigeria, unpublished Ph.D Thesis, Department of Agricultural Economics, (2006), University of Ibadan. 
Olajide, S.O. and E.O. Heady, 1982. Introduction to Agricultural Economics, Ibadan University Press, Ibadan, Nigeria.

Oluwafemi R.A et al., H. (2010). The impact o Agricultural credit on livestock production and owners livelihood. The case of livestock farmers in ovia North East LGA of Edo State, Nigeria. International Journal of Business and common Market study. 6(2), 34-35.

Ogundari K., Ojo S.O. and Ajibefun I.A. (2006). Economics of scale and cost efficiency in small scale maize production: Empirical Evidence from Nigeria, Journal of Social Science, 13(2): 131-136.

Oke O. L. (1990). Roots, Tubers, Plantain and Bananas in Human Nutrition, FAO Food and Nutrition series No 24.

Reuben J, Barau A.D.(2012). Resource use efficiency in yam production in Taraba State, Nigeria. J. Agric. Sci., 3(2)71-77.

Schmidt P (1976). On the Statistical Estimation of Parametric Frontier Production Functions: Review of Economics and Statistics, 58:238 - 239.

Udoh, E.J. (2003), Land Management Resource, Use Efficiency among farmers in south Eastern Nigeria, unpublished. Ph.D Thesis, Department of Agricultural Economics, (2003), University of Ibadan.

Udoh, E.J., 2005. Technical in Efficiency in vegetable farms of humid region, an analysis of dry season by urban women in south-South zone, Nigeria. J. Agric. Soc. Sci., 1:80-85 